\title{
PERUBAHAN SOSIAL DALAM TARIAN SEUDATI PADA MASYARAKAT ACEH
}

\author{
Meipur Yanti \\ Program Pascasarjana, Universitas Negeri Semarang \\ E-mail: meipuryanti.mp@gmail.com
}

\begin{abstract}
Abstrak
Agama Islam dan budaya masyarakat Aceh merupakan satu kesatuan. Agama Islam menjadi sumber utama dalam kebudayaan masyarakat Aceh, sehingga semua kesenian di Aceh, dalam hal ini seni tari, selalu dikaitkan dengan nilai keagamaan. Tari Seudati yang merupakan warisan budaya nenek moyang orang Aceh adalah salah satu tarian tradisional yang terus dilestarikan dan berkembang di kalangan masyarakat Aceh secara nasional maupun internasional. Proses perubahan meliputi: proses reproduksi dan proses transformasi, dari masa ke masa, dan mengikuti perkembangan zaman. Tari Seudati mengalami beberapa kali perubahan sosial, dikarenakan adanya penambahan norma-norma, nilai-nilai, adat, dan agama di masyarakat Aceh. Hasil dari perubahan sosial pada Tari Seudati kini terbagi menjadi dua yaitu: seudati agam (seudati laki-laki) sebagai tari tradisional dan seudati inong (seudati perempuan) sebagai tari kreasi. Seudati inong merupakan pengembangan dari seudati agam. Walaupun ada beberapa kali perubahan sosial dalam Tari Seudati, masyarakat Aceh tetap mengikuti norma-norma, nilai-nilai, adat, dan agama yang telah ditanamkan pada diri masyarakat Aceh sejak dahulu.
\end{abstract}

Kata kunci: perubahan sosial, tari seudati, masyarakat aceh

\section{SOCIAL CHANGES IN SEUDATI DANCE IN ACEH SOCIETY}

\begin{abstract}
The religion of Islam and the culture of the people of Aceh is a unity. Islam is a major source of Acehnese culture, so that Art in Aceh, in this case dance, is always associated with religious values. Seudati Dance which is the cultural heritage of Acehnese ancestors is one of the traditional dances that continues to be preserved and developed among the people of Aceh nationally and internationally. The process of changes includes: the process of reproduction and the process of transformation, from time to time, keeping up with the changing times. Seudati dance experienced several times of social change, due to the addition of norms, values, customs, and religion in the people of Aceh. The result of social changes in Seudati Dance are now divided into two: seudati agam (seudati male) as traditional dance and seudati inong (seudati female) as dance creations. Seudati inong is the development of seudati agam. Although there are several times of social change in Seudati Dance, the people of Aceh still follow the norms, values, customs, and religions that have been implanted on Acehnese society long ago.
\end{abstract}

Keywords: social changes, Seudati dance, Aceh society

\section{PENDAHULUAN}

Tari adalah suatu pertunjukan yang melibatkan seluruh elemen masyarakat pendukungnya, yang juga merupakan warisan budaya leluhur dari beberapa abad yang lampau. Tari tercipta sesuai dengan kebudayaan setempat 
dengan cara, bentuk, dan dalam konteks yang berbeda-beda. Tari biasanya difungsikan baik untuk kegiatan yang sakral maupun sekedar sebagai sarana hiburan. Seperti kegiatan yang berkaitan dengan religi, adat, kepercayaan, dan ada juga yang berfungsi sebagai hiburan atau rekreasi. Sistem sosial dan lingkungan alam juga mempengaruhi bentuk dan fungsi tari pada suatu suku (etnik) dan budaya, yang sudah menjadi tradisi bagi masyarakatnya.

Sebagai bagian dari tradisi, kesenian merupakan rangkaian aktivitas dari budaya masyarakatnya yang tidak bisa berdiri sendiri. Kehidupan kesenian setiap etnik, berhubungan erat dengan aspek keagamaan. Demikian juga yang dilakukan oleh masyarakat Aceh dalam berkesenian. Agama Islam dan budaya dalam masyarakat Aceh menjadi satu kesatuan. Oleh karena itu, agama Islam menjadi sumber utama dalam kebudayaan masyarakat Aceh. Aceh dianggap sebagai tempat dimulainya penyebaran Islam di Indonesia dan memainkan peran penting dalam penyebaran Islam di Asia Tenggara. Pada awal abad ke-17, Kesultanan Aceh adalah wilayah terkaya, terkuat, dan termakmur di kawasan Selat Malaka. Aceh adalah wilayah yang sangat konservatif (menjunjung tinggi nilai agama). Persentase penduduk Muslimnya adalah yang tertinggi di Indonesia dan mereka hidup sesuai syariah Islam. Berbeda dengan kebanyakan provinsi lain di Indonesia, Aceh memiliki otonomi yang diatur tersendiri karena alasan sejarah. Sehingga semua kesenian di Aceh selalu mengkaitkan nilai keagamaannya termasuk kesenian dalam hal ini adalah seni tari.

Dalam hal ini hasil karya manusia yang dibahas adalah karya mengenai seni tari yang ada dan berkembang dikalangan masyarakat Aceh pada zaman sekarang ini yaitu Tari Seudati, saman, ranub rateb dll. Yang mana seperti yang telah diterangkan diatas bahwasannya semua tarian tradisional yang ada di Aceh selalu berkaitan dengan nilai Agama. Salah satu tarian tradisonal yang di maksud adalah tarian seudati, dimana syair yang terkandung dalam tarian Seudati ini adalah berisikan tentang sanjungan dan pujian kepada Allah dan RasulNya.
Perkembangan dan kepopuleran tari sangat ditentukan oleh peran suatu lembaga masyarakat atau sanggar. Sanggar merupakan salah satu wadah untuk memperkenalkan, mengasah, mengembangkan, dan mempelajari suatu seni, khususnya seni tari. Dalam proses pembelajaran seni tari terdapat dua faktor yang mempengaruhi proses belajar itu sendiri, yaitu faktor individu dan sosial. Salah satu sanggar yang berperan aktif dalam proses pengembangan seni tari yang ada di Banda Aceh adalah Sanggar Lempia. Sanggar ini terletak di Lampaseh Kota, Kec. Kuta Raja, Banda Aceh yang dikoordinasi oleh Zufli Hermi. Sanggar lempia merupakan salah satu sanggar yang tergolong banyak memperkenalkan tari tradisional Aceh, salah satunya yaitu tari Seudati dan tari kreasi yaitu tari kreasi seudati inong (seudati perempuan), yang mana kreasi seudati inong ini adalah pengembangan dari seudati agam (seudati laki-laki).

Zulfi Hermi (2014) menurut sejarahnya tari seudati berasal dari Kabupaten Pidie sebelum masuknya ajaran islam ke Aceh tarian Seudati ini ditarikan oleh kaum perempuan, yang mana kaum perempuan hanya tinggal dirumah dan menjaga anak sedangkan para lelaki bekerja mencari nafkah. Namun setelah masuk ajaran islam ke Aceh, bahwa sannya para perempuan tidak di izinkan untuk menari, ataupun melenggak lenggokkan tubuh di depan umum, kemudian karna masyarakat Aceh menyukai seni maka tari ini di gantikan penarinya oleh para lelaki dan syair yang terdapat pada tari seudati ini dirubah menjadi sanjungan dan pujian kepada Allah dan RasulNya, tari ini disebut dengan tari seudati agam.

Menurut Isjkarim dkk (1981:48) menurut penelitian para ahli-ahli sejarah dan orang tua, tumbuhnya Tari Seudati ini bersamaan dengan masuknya agama islam di Aceh. Sebelum tari ini disebut seudati, tari ini bernama Ratoh yang artinya menceritakan, dalam ratoh ini menceritakan segala sesuatu yang menyangkut aspek kehidupan masyaraka seperti: kisah sedih, gembira, nasehat dan membangkitkan semangat.

Setelah masuknya ajaran islam ke Aceh tarian ini juga digunakan oleh para tokoh agama 
sebagai media dakwah dalam menyebarkan agama Islam. Namun pada masa penjajahan Belanda tarian ini sempat dilarang. Karena syair yang dibawakan dalam Tari Seudati ini dianggap dapat menumbuhkan semangat bagi para pemuda Aceh untuk bangkit dapat menimbulkan pemberontakan kepada Belanda. Setelah kemerdekaan Indonesia, tarian ini kembali diperbolehkan, bahkan tidak hanya sebagai media dakwah, tapi juga sering ditampilkan sebagai tarian pertunjukan hingga sekarang. Hal tersebut juga berkaitan dengan syair-syair yang dilantunkan dalam mengiringi tarian ini. Syair tersebut biasanya berisi tentang kehidupan dan ajaran agama. Selain itu setiap gerakan dalam Tari Seudati ini juga tentu memiliki nilai-nilai dan makna khusus di dalamnya.

Tari Seudati sampai saat ini masih terus berkembang dan dilestarikan, dan juga sering ditampilkan diacara-acara formal maupun non formal. Tarian seudati ini sering di jadikan suatu ajang festifal yang berada di Aceh, kemudian tari Seudati sudah sangat dikenal di kalangan masyarakat maupun ditingkat nasional hingga internasional. Tari Seudati yang sebelumnya di tarikan oleh para lelaki, kini kembali lagi ditarikan oleh para perempuan yang di sebut tari Seudati Inong (seudati perempuan) yang mana tarian ini pengembangan dari seudati agam (seudati laki-laki). Dan saat sekarang ini tari ini terbagi atas dua yaitu tari seudati agam dan tari seudati inong bahkan ada yang menyebut tari seudati inong ini adalah tari lawet.

Zulfi Hermi (2014) mengatakan bahwa tarian kreasi Seudati Inong berkembang sejak tahun 1985 di sanggar Lempia Banda Aceh dan dikembangkan oleh syah Zulfi Hermi”. Tarian kreasi Seudati Inong ini dipimpin oleh seorang syakh (pimpinan). Syakh ini dibantu oleh wakil yang disebut apet syakh dan apet syakh berdiri di kiri dan kanan syakh pada barisan depan, jumlah di dalam penari Seudati ada 8 orang, tarian ini memiliki babak-babak tertentu yang harus dijalankan.

Mengamati dan memahami tari Seudati ini, maka penulis tertarik untuk melihat perubahan sosial dalam tarian seudati yang terjadi di kalangan masyarakat aceh, yang mana tari seudati dari masa kemasa mengalami proses perubahan, mengikuti alur perkembangan zaman.

\section{PEMBAHASAN}

Menurut Roy Bhaskar 1984 (dalam Wiryahardoyo 2002: 20) perubahan sosial biasanya terjadi secara wajar (naturally), gradual, berharap serta tidak pernah terjadi secara radikal atau revolusioner. Proses perubahan meliputi: proses reproduction dan proses transpormation. Proses reproduction adalah proses mengulangulang, menghasilkan kembali segala hal yang diterima sebagai warisan budaya dari nenek moyang kita sebelumnya. Dalam hal ini meliputi warisan bentuk budaya yang kita miliki. Warisan budaya dalam kehidupan keseharian meliputi material (kebendaan, teknologi), immaterial (non- benda, adat norma dan nilai). Roy Bhaskar menyatakan, reproduction berkaitan dengan masa lampau perilaku masyarakat, yang berhubungan dengan masa sekarang dan masa yang akan datang. Transpormasi merupakan suatu proses masa depan yang menjadi ancaman prilaku yang lepas dari dasar prilaku strukturalrnya telah tertanam pada masa sekarang dan masa lalu. Dengan demikian transpormasi masa depan bukanlah prilaku yang lepas dari dasar kegiatan manusia pada masa sekarang serta masa lalunya. Kondisi ini berlaku pada masyarakat dunia, yang menerima perubahan sebagai proses kematangan sehingga sebenarnya perubahan sosial akan berjalan dengan menapak sebagai penahapan model kematangan prilaku manusia, dari satu masa kemasa yang lain. Setiap jenis kematangan akan mengikuti aspek yang telah dilakukan, jauh sebelum sebuah perilaku masyarakat berubah pada masa kini. Pada masa sekarang ini yang banyak dilakukan orang adalah mengulang-ulang apa yang pernah kita miliki, sehingga hanya sedikit sekali kesempatan untuk mengubahnya atau mengadakan perbaharuan secara silmutan.

Proses transformation, adalah suatu proses penciptaan hal yang baru yang dihasilkan oleh ilmu pengetahuan dan teknologi, yang berubah adalah aspek budaya yang sifatnya material, 
sedangkan yang sifatnya norma dan nilai sangat sulit sekali diadakan perubahan (bahkan ada kecenderungan untuk dipertahankan. Hal ini menunjukan bahwa budaya yang tampak (material) lebih mudah diubah, tetapi sikap hidup adalah menyangkut nilai-nilai yang sukar untuk dibentuk kembali.

Menurut Harper 1989 (dalam Martono 2013:5) perubahan sosial didefinisikan sebagai pergantian (perubahan) yang signifikan mengenai struktur sosial dalam kurung waktu tertentu. Perubahan didalam struktur ini mengandung beberapa tipe perubahan struktur sosial, yaitu: pertama, perubahan personal yang berhubungan dengan perubahan-perubahan peran dan individu-individu baru dalam sejarah kehidupan manusia yang berkaitan dengan keberadaan struktur. Perubahan dalam tipe ini bersifat gradual (bertahap) dan tidak banyak unsurunsur baru maupun unsur-unsur yang hilang. Perubahan ini dapat dilihat misalnya dalam perubahan peranan dan fungsi perempuan dalam masyarakat. Jika sebelumnya perempuan di posisikan sebagai subjek yang memegang peran dan fungsi di wilayah domestik (di alam rumah). Namun sebagai mana dilihat dalam masyarakat modern, perempuan sudah ikut berperan serta dalam wilayah publik yang sebelumnya hanya ditempati laki-laki. Tentu saja perubahan ini membawa berbagai konsekuensi, seperti dalam masalah pengasuhan anak, harmonisasi keluarga, dan sebagainya.

Kedua, perubahan dalam cara bagianbagian struktur sosial berhubungan, perubahan ini misalnya terjadi pada perubahan alur kerja birokasi dalam lembaga pemerintahan. Jika sebelumnya system kerja aparat pemerintah masih manual (mengunakan tenaga manusia) maka sekarang dapat dilihat hampir berbagai sistem pelayanan pemerintahan telah tergantikan secara mekanis menggunakan teknologi canggih, sehinggasegala sesuatu menjadi serba online. Hal ini mempengaruhi peubahan dan cara kerja aparat pemerintah dalam memberikan pelayanan kepa publik.

Ketiga, perubahan dalam fungsi-fungsi struktur, berkaitan dengan apa yang lakuka masyarakat dan bagaimana masyarakat tersebut melakukannya. Pada masyarakat tradisional, keluarga memegang peran penting dalam, menjalankan fungsi pendidikan, karena pada saat itu pendidikan masih berkutat dalam transfer nilai antar orang tua dengan anak,. Seiring perkembangan jaman, peran untuk memberikan pendidikan telah tergantikan lembaga pendidikan di luar keluarga, yaitu sekolah menjadi sebuah kebutuhan pokok bagi masyarat modern.

Keempat, perubahan dalam hubungan struktur yang berbeda. Lembaga pendidikan dalam masyarakat industry memiliki fungsi menyiapkan tenaga kerja untuk kepentingaan industrri. Hal ini mengakibatkan adanya saling keterkaitan antara lembaga pendidikan dengan dunia usaha, subtansi (muatan) pendidikan pada saat sekarang lebih diarahkan untuk menyesuaikan kondisi atau kebutuhan dunia kerja.

Kelima, kemunculan struktur baru, yang merupakan pristiwa munculnya struktur baru untuk menggantikan struktur sebelumnya. Perubahan dalam hal ini dapat melihat misalnya munculnya KPK. Pemberantasan korupsi pada awalnya menjadi petugas kepolisian, namun dengan berbentuknya KPK, peran kepolisian dalam melakukan penyelidikan masalah korupsi telah tergantikan.

Menurut Himes dan Moore (dalam Ranjabar 2015:4) perubahan sosial mempunyai tiga dimensi, yaitu: dimensi structural, cultural, dan interaksional. Pertama, dimensi structural mengacu pada perubahan-perubahan daam bentuk struktu masyarakat, menyangkut perubahan dalam peran, munculnya peranan baru, perubahan dalam struktur kelas sosial, dan perubahan dalam lembaga sosial. Perubahan tersebut meliputi; menyangkut aspek perilaku da kekuasaan; adanya peningkatan ataupun penurunan sejumlah peranan atau pengategorian peranan; terjadinya pergeseran dari waktu atau kategori peranan; terjadinya modifikasi saluran komunikasi di antara peranan-peranan atau kategori peranan; dan terjadinya perubahan sejumlah tipe dan daya guna fungsi sebagai akibat perubahan struktur. 
Kedua, dimensi cultural mengacu pada perubahan kebudayaan dalam masyarakat. Perubahan ini meliputi: pertama, inovasi kebudayaan. Inovasi kebudayaan merupakan komponen internal yang memunculkan perubahan sosial dalam suatu masyarakat. Inovasi kebudayaan yang paling mudah ditemukan adalah munculnya teknologi baru. Kebutuhan masyarakat yang semangkin kompleks memaksa individu untuk berfikir kreatif dalam upaya memenuhi kebutuhan tersebut. Kedua, difusi. Difusi merupakan komponen eksternal yang mampu menggerakkan terjadinya perubahan dari budaya lain, yang hal tersebut kemudian memicu perubahan kebudayaan dalam masyarakat yang "menerima" unsure-unsur kebuayaan tersebut. Ketiga, integrasi. Intergrasi merupakan wujud perubahan budaya uang "relative lebih halus". Hal ini disebabkan dalam proses terjadi penyatuan unsur-unsur kebudayaan yang saling bertemu untuk kemudian memunculkan kebudayaan baru sebagai hasil penyatuan sebagai unsur-unsur budaya tersebut.

Ketiga, dimensi interaksional mengacu pada adanya perubahan hubungan sosial dalam masyarakat. Dimensi ini melipu: pertama, perubahan dalam frekuensi. Perkembangan teknologi telah menyebabkan berkurangnya fekunsi individu untuk saling bertatap muka. Semua keseluruhan untuk berinteraksi dapat dipenuhi dengan memanfaatkan teknologi. Seorang nasabah bank telah tergantikan oleh mesin ATM yang mampu melayani nasabah selama 24 jam dimana saja, tanpa harus mengantri lama, atau mengisi formulir tertentu. Kedua, perubahan dalam jarak sosial. Perkembangan teknologi informasi dan komunikasi telah menggeser fungsi "tatap muka" dalam proses interaksi. Individu tidak harus bertatap muka untuk dapat melakukan komunikasi dan interaksi secara langsung. Bahkan ketika dua individu berada ditempat yang sangat jauh, mereka tetap dapat berkomunikasi meskipun dalam jarak ribuan meter. Ketiga, perubahan aturan atau pola-pola. Banyak aturan serta pola-pola hubungan yang mengalami perubahan seiring perkembangan masyarakat. Emansipasi perempuan dalam duniia kerja misalnya, telah mengacu cara pandang masyarakat dalam menyikapi "perempuan yang pulang malam". Bila sebelumnya perempuan yang sering keluar atau pulang malam di konotasikan sebagai "perempuan nakal", namun sekarang masyarakat telah memandang hal tersebut biasa karna pada saat sekarang banyak perempuan yang bekerja sampai larut malam atau bahkan kerja pada malam hari.

Tari Seudati adalah salah satu tarian tradisional yang berasal dari daerah Aceh. Tari ini biasanya dibawakan secara berkelompok dengan gerakannya yang khas dan enerjik serta diiringi oleh lantunan syair dan suara hentakan para penari. Tari Seudati ini merupakan salah satu tarian tradisional yang cukup terkenal di daerah Aceh, dan sering ditampilkan di berbagai acara, baik acara adat, acara pertunjukan, dan acara budaya.

Penganjur-penganjur Islam yang kebanyakan berasal dari Arab maka secara langsung bahasa atau istilah yang dipergunakan dalam penyebaran Agama dititik beratkan pada istilah bahasa Arab. Maka sekaligus media ratoh ini di pengaruhi dengan istilah-istilah Arab. Dari syahadati dan syahadatain menjadi seudati.

Kedua istilah ini dipergunakan sampai sekarang. Ada pula pendapat lain yang mengatakan bahwa kata Seudati berasal dari kata seurasi (artinya harmonis/kompak). Dahulu seudati ini berkembang di kabupaten Pidie dan Kabupaten Aceh Utara. Sekarang sudah berkembang di Kabupaten Kota Madya lainnya dalam Daerah Istimewa Aceh.

Namun ada yang mengatakan Zulfi Hermi (2014) menurut sejarahnya sebelum masuknya ajaran islam ke Aceh tarian seudati ini ditarikan oleh kaum perempuan, yang mana kaum perempuan hanya tinggal dirumah dan menjaga anak sedangkan para lelaki bekerja mencari nafkah. Dikarnakan dulu jarak rumah didesa itu sangat jauh dan jarang sekali bisa bersilaturahmi maka ibu-ibu yang tidak ada berkegiatan ini membuat suatu perkumpulan yang mana perkumpulan ini membuat satu kesenian yaitu tari seudati, tari ini di tarikan secara lemah lembut dan syairnya menceritakan perjuangan hidup tarian ini dulu hanyalah tarian yang dibuat 
hanya sekedar untuk menghibur diri dan untuk kesenangan semata.

Pada masa itu kesenian Aceh sangatlah minim yang mana kurangnya sosialisasi dan komunikasi antar masyarakat yang dikarnakan jarak antar rumah kerumah sangatlah jauh, kemudian kesenian yang ditampilkanpun bukanlah dipanggung melainkan di bawah kolong rumah, yang mana seperti rumah adat Aceh yang memiliki tiang-tiang rumah yang tinggi untuk menghindari hewan buas.

Namun setelah masuk ajaran islam ke Aceh, bahwa sannya para perempuan tidak di izinkan untuk menari, ataupun melenggak lenggokkan tubuh di depan umum, kemudian karna masyarakat Aceh menyukai seni maka tari ini tetap ada hanya saja penarinya di gantikan oleh penari laki-laki dan syair yang terdapat pada Tari Seudati ini dirubah menjadi sanjungan dan pujian kepada Allah dan RasulNya, tari ini disebut dengan tari seudati agam (seudati lakilaki). Pada masa ini hamper semua kesenian berkaitan erat dengan ajaran-ajaran agama, seperti pada karya seni rupa yaitu benda berperang "rencong" bentuknya seperti tulisan bismillah, sedangkan seni tari dan musik, syairnya tentang sanjungan dan pujian kepada Allah beserta RasulNya, dan kesenian pada saat itu dijadikan sarana media dakwah.

Setelah masuknya ajaran islam ke Aceh tarian ini juga digunakan oleh para tokoh agama sebagai media dakwah dalam menyebarkan agama Islam. Namun pada masa penjajahan Belanda tarian ini sempat dilarang. Karena syair yang dibawakan dalam Tari Seudati ini dianggap dapat menumbuhkan semangat bagi para pemuda Aceh untuk bangkit dapat menimbulkan pemberontakan kepada Belanda. Setelah kemerdekaan Indonesia, tarian ini kembali diperbolehkan, bahkan tidak hanya sebagai media dakwah, tapi juga sering ditampilkan sebagai tarian pertunjukan hingga sekarang. Hal tersebut juga berkaitan dengan syair-syair yang dilantunkan dalam mengiringi tarian ini. Syair tersebut biasanya berisi tentang kehidupan dan ajaran agama. Selain itu setiap gerakan dalam Tari Seudati ini juga tentu memiliki nilai-nilai dan makna khusus di dalamnya.
Tari Seudati sampai saat ini masih terus berkembang dan dilestarikan, dan juga sering ditampilkan diacara-acara formal maupun non formal. Tarian Seudati ini sering di jadika suatu ajang festival yang berada di Aceh, kemudian Tari Seudati sudah sangat dikenal di kalangan masyarakat maupun ditingkat nasional hingga internasional. Setelah berjalannya waktu terus menerus hingga perubahan perkembangan zaman, dan kebutuhan masyarakat juga berbeda. kesenian di Aceh semakin berkembang pesat dengan adanya festival-festival yang selalu di gelar di Aceh. Seni sangat banyak membawa perubahan pola pikir yang terhadap pada masyaraka Aceh, dan seni sekarang menjadi sebuah kebutuhan bagi orang Aceh. Dimana saat sekarang ini masyarakat mulai memikirkan perkembangangan tentang kesenian daerahnya, untuk memajukan dan memperkenalkan budayanya ke macanegara. Dan pada akhirnya Aceh sekarang dijadikan salah satu wisata distinasi wisata halal. Semakin berkembangnya seni di Aceh maka pola pikir koreografi pun semakin berkembang sehingga saat sekarang ini perempua Aceh kembali di ijinkan menari di atas panggung atau ditempat umum, seperti tempat pertunjukan maupun diajang festifal namun tetaplah penari perempuan yang berada di Aceh harus menarikan secara lemah lembut layaknya wanita Aceh. Atau seperti kebanyakan tarian duduk yang dibawakan perempuan Aceh, begitu pula pada busanya harus tetap menutup aurat.

Tari Seudati yang sebelumnya di tarikan oleh para lelaki, kini kembali lagi ditarikan oleh para perempuan yang di sebut tari Seudati Inong (seudati perempuan) yang mana tarian ini pengembangan dari seudati agam (seudati laki-laki), gerakan yang ada pada lelaki hanya sedikit di rubah menjadi di perlembut dan di perhalus, sedangkan syairnya tetap berisikan tentang sanjungan dan pujian kepada Allah dan RasulNya. Perubahan ini di karnakan kebutuhan perkembangan zaman dan sebagai sarana kebutuhan kesenian yang ada di masyarakat Aceh. Dan saat sekarang ini tari ini terbagi atas dua yaitu tari seudati agam (seudati laki-laki) sebagai tari tradisional sedangkan tari seudati inong (seudati perempuan) sebagai tarian 
kreasi bahkan ada yang menyebut tari seudati inong (seudati permpuan) ini adalah tari lawet (salawat).

Zulfi Hermi (2014) “ tarian kreasi seudati inong berkembang sejak tahun 1985 di sanggar Lempia Banda Aceh dan dikembangkan oleh syah Zufli Hermi”. Tarian kreasi Seudati Inong ini dipimpin oleh seorang syakh (pimpinan). Syakh ini dibantu oleh wakil yang disebut apet syakh dan apet syakh berdiri di kiri dan kanan syakh pada barisan depan, jumlah di dalam penari seudati ada 8 orang, tarian ini memiliki babak-babak tertentu yang harus dijalankan.

\section{Tari tradisional seudati agam (seudati laki-laki)}

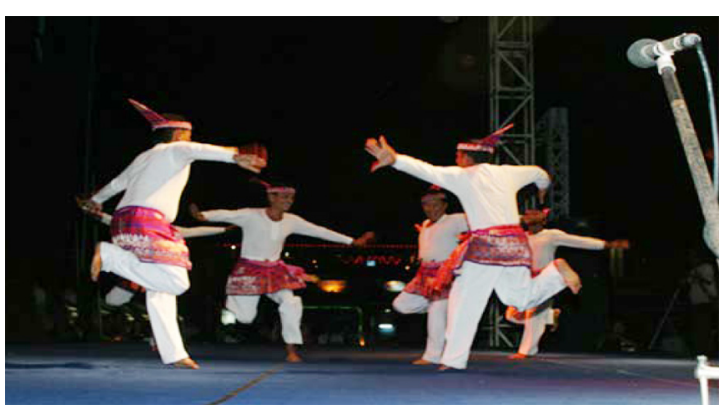

Gambar 1. Penari seudati agam

Seudati ditarikan oleh delapan orang lakilaki sebagai penari utama, terdiri dari satu orang pemimpin yang disebut syeikh, satu orang pembantu syeikh, dua orang pembantu di sebelah kiri yang disebut apeetwie, satu orang pembantu di belakang yang disebut apeet bak, dan tiga orang pembantu biasa. Selain itu, ada pula dua orang penyanyi sebagai pengiring tari yang disebut aneuk syahi.

Jenis tarian ini tidak menggunakan alat musik, tetapi hanya membawakan beberapa gerakan, seperti tepukan tangan ke dada dan pinggul, hentakan kaki ke tanah dan petikan jari. Gerakan tersebut mengikuti irama dan tempo lagu yang dinyanyikan. Bebarapa gerakan tersebut cukup dinamis dan lincah dengan penuh semangat. Namun, ada beberapa gerakan yang tampak kaku, tetapi sebenarnya memperlihatkan keperkasaan dan kegagahan si penarinya. Selain itu, tepukan tangan ke dada dan perut mengesankan kesombongan sekaligus kesatria.

Busana tarian Seudati terdiri dari celana panjang dan kaos oblong lengan panjang yang ketat, keduanya berwarna putih; kain songket yang dililitkan sebatas paha dan pinggang; rencong yang disisipkan di pinggang; tangkulok (ikat kepala) yang berwarna merah yang diikatkan di kepala; dan sapu tangan yang berwarna. Busana seragam ini hanya untuk pemain utamanya, sementara aneuk syahi tidak harus berbusana seragam. Bagian-bagian terpenting dalam tarian seudati terdiri dari likok (gaya; tarian), saman (melodi), irama kelincahan, serta kisah yang menceritakan tentang kisah kepahlawanan, sejarah dan tematema agama.

Pada umumnya, tarian ini diperagakan di atas pentas dan dibagi menjadi beberapa babak, antara lain: babak pertama dimulai dengan saleum (sapa-menyapa) dari aneuk syahi saja, sedang penari/pemain hanya menari saja dengan bermacam lenggak-lengok, tepuk dada, gerakangerakan yang elastic, serta deripan jari-jari yang bertingkah mengikuti gerak irama lagu. Babak kedua : 1) bak samn, 2) likok, 3)saman, 4) kisah, dan 5) lanie.

Didalam tari seudati agam juga memiliki beberapa nama gerak dan formasinya yaitu sebgai berikut: sago, apet wie, syeah, apet uneun, apet likok, berbanjar, pharangkang, cicem po, gilong.

\section{Taati kreasi seudati inong (seudati perempuan)}

Tari Seudati inong ini dimainkan oleh para penari permpuan. Penari tersebut biasanya berjumlah 8 orang penari utama yang terdiri dari satu orang syeh, satu pembantu syeh, dua apeet, satu apeet bak dan tiga orang pembantu biasa. Selain itu dalam tarian ini juga terdapat dua orang lain yang bertugas sebagai pelantun syair yang disebut aneuk syahi. 


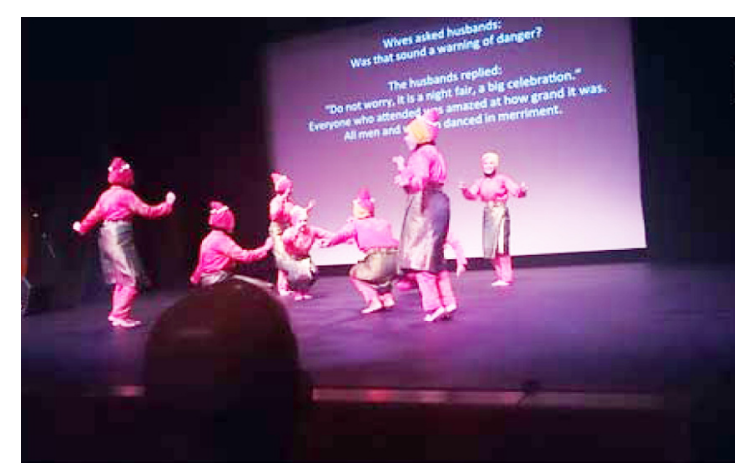

Gambar 2. Penari seudati inong

Gerakan dalam Tari Seudati inong ini sangat khas, enerjik, dan lugas. Gerakan dalam tarian ini didominasi oleh gerakan tangan dan kaki serta didukung dengan pola lantai yang bervariasi. Gerakan yang paling menonjol biasanya gerakan tepuk paha, ketipan jari, jerak tangan dan hentakan kaki yang dilakukan dengan lincah, cepat dan harmonis. Sehingga tak jarang membuat penonton terkagum-kagum menyaksikan pertunjukan Tari Seudati ini.

Kostum yang digunakan para penari dalam Tari Seudati inong ini biasanya menggunakan kostum khusus yang bertemakan adat. Kostum yang digunakan biasanya terdiri dari baju aceh berlengan panjang dan celana panjang. Baju dan celana tersebut biasanya tidak di patokkan. Sedangkan sebagai aksesoris biasanya terdiri dari kain songket yang dikenakan di pinggang hinga lutut, hingga aksesoris kepala seperti jilbab dll.

Pada umumnya, tarian ini diperagakan di atas pentas dan dibagi menjadi beberapa babak, antara lain: babak pertama dimulai dengan saleum (sapa-menyapa)dari aneuk syahi saja, sedang penari/pemain hanya menari saja dengan bermacam lenggak-lengok, tepuk dada, gerakangerakan yang elastic, serta deripan jari-jari yang bertingkah mengikuti gerak irama lagu. Babak kedua : 1) bak samn, 2) likok, 3)saman, 4) kisah, dan 5) lanie.

Didalam Tari Seudati inong juga memiliki beberapa nama gerak dan formasinya yaitu sebgai berikut: dua bershaf, satu bershaf, pharangkang/ jambo, rangkang, likok pesawat, blong, giring, jurung, jalan sago, nyap, puta ule dan dua banjar
Dari kedua Tari Seudati ini dapat kita lihat perbedaanya sebagai berikut

1. Trari seudati agam sudah ditetapkan sebagai tari tradisional sedangkan tari seudati inong dianggap sebagai tarian kreasi baru

2. Dari bentuk gerak perbedannya dalah laki-laki gerakannya kokoh dan berenergi sedangkan gerakan seudati inong gerakannya tetap, ligat, sedikit lebih lembut dan centil.

3. Berbeda ragam gerak dan pormasi

4. Busana yang digunakan juga berbeda.

Penggunaan dalam menganalisi perubahan sosial dalam Tari Seudati ini penulis menggunakan teori yang dikemukakan oleh Roy Bhaskar 1984 (dalam Wiryahardoyo 2002:20) perubahan sosisal biasanya terjadi secara wajara (naturally), gradual, berharap serta tidak pernah terjadi secara radikal atau revolusioner. Proses perubahan meliputi: proses reproduction dan proses transpormation. Seperti yang sudah dijelaskan di deskripsi Tari Seudati maka hasil analisisnya adalah sebagai berikut;

Tari Seudati adalah tari tradisioal yang mengalami beberapa kali perubahan. Perubahan yang pertama, dikarenakan masuknya ajaran Islam ke Aceh sehinnga membuat perubahan dan norma-norma yang baru yang di berlakukan di kalangan masyarakat Aceh. Tarian yang dulunya ditarikan oleh perempuan kini sudah ditarikan oleh laki-laki. Tari ini ditetapkan sebagai tari tradisional. Perubahan yang kedua dikarnakan, perkembangan zaman modern dan sebagai sarana kebutuhan bagi masyarakat. Yang mana haus akan kesenian, sehingga merubah pola piker masyarakat untuk kesenian lebih tinngi, kemudian saat sekarang ini kembalinya tarian seudati yang di tarikan oleh perempuan yaitu dinamakan Tari Seudati inong ditetapkan sebagai tari kreasi. Kedua tari ini masih berkembang dan dilestarikan di masyarakat aceh.

Perbedaan yang terlihat dari tari Seudati Agam dan seudati inong adalah dari segi busana, busana yang digukan seudati agam tidak pernah berubah karena sudah ditetapkan menjadi tari tradisional, sedangkan Tari Seudati inong busananya bisa berubah-ubah sesuai dengan acara karena tarian ini di tetapkan sebagai tari 
kreasi, kemudian dapat dilihat dari babak dan gerak tari, sedangkan syair disesuaikan menurut acara yang digelar, tetapi tepap menggunakan syair yang berisikan tentang nasehat.

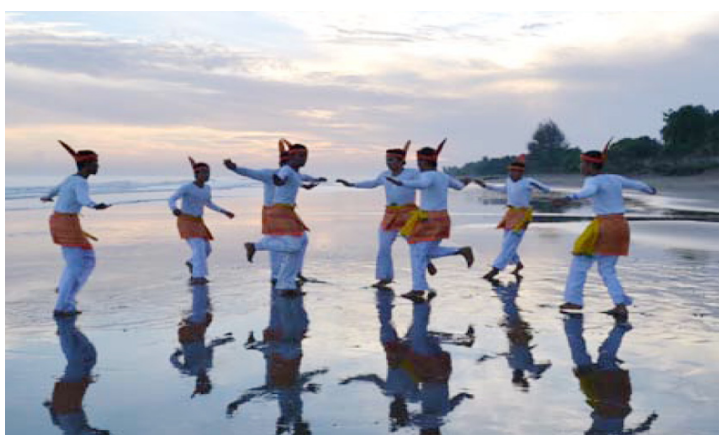

Gambar busana dan gerak tari seudati agam

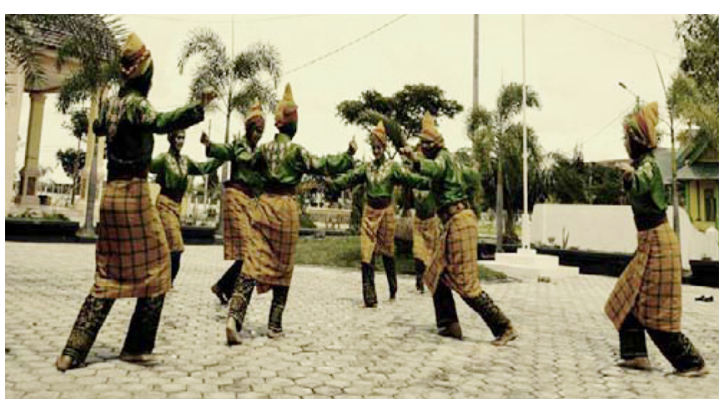

Gambar busana dan gerak tari seudati inong

Aceh dianggap sebagai tempat dimulainya penyebaran Islam di Indonesia dan memainkan peran penting dalam penyebaran Islam di Asia Tenggara. Pada awal abad ke-17, Kesultanan Aceh adalah wilayah terkaya, terkuat, dan termakmur di kawasan Selat Malaka. Aceh adalah wilayah yang sangat konservatif (menjunjung tinggi nilai agama). Persentase penduduk Muslimnya adalah yang tertinggi di Indonesia dan mereka hidup sesuai syariah Islam. Berbeda dengan kebanyakan provinsi lain di Indonesia, Aceh memiliki otonomi yang diatur tersendiri karena alasan sejarah. Sehingga semua kesenian di Aceh selalu mengkaitkan nilai keagamaannya termasuk kesenian dalam hal ini adalah seni tari. Tari Seudati mengalami beberapa kali perubahan karena Islam mengajarkan wanita untuk menutup aurat dan tidak boleh melenggak lenggokkan tubuh di depan umum sehiningga kemudian di gantikan oleh penari laki-laki. Pada masa modern mengikuti perkembangan zaman perempuan boleh menari tetapi dengan gerakan yang anggun dan berpakayan tertutup tanpa mengurangi norma-norma yang telah ada.

Pertama, tujuan dari perubahan ini adalah untuk mematuhi dan menjaga norma-norma yang diberlakukan pada saat sekarang ini karena Aceh merupakan pemegang agama Islam terbesar di Indonesia. Tujuan yang kedua adalah untuk tidak lagi didalam keterpurukan di dalam bidang kesenian karena Aceh sebenarnya memiliki begitu banyak budaya yang seharusnya dilestarikan, diperkenalkan, dikembangkan dan diwariskan.

Perubahan pada Tari Seudati memakan waktu yang sangat lama dimana perubahan itu secara bertahap dan beransur-ansur mengikuti perkembangan zaman sesuai kebutuhan masyarakat Aceh. perubahan yang di maksud bertahap dan beransur-ansur adalah dimana masyarakat Aceh harus menyepakati bersama tentang perubahan baru yang dibuat sesuai dengan norma-norma, nila dan adat yang berlaku pada masyarakat Aceh.

Perubahan terjadi dikarnakan perkembangan zaman yang berubah-ubah sehingga masyarakat Aceh mengikuti proses perkembangan zaman seperti layaknya masyarakat pada umumnya dengan tujuan untuk perubahan yang lebih baik dan berkembang sesuai dengan zamannya. Tidak mudah bagi orang Aceh mengikuti perkembangan zaman, karna harus di sesuaikan dengan norma-norma, nilai-nilai, adat dan agama yang telah ditanam di diri masyarakat Aceh.

Faktor yang berperan dalam perubahan meliputi: adanya penambahan norma-norma, nilai-nilai, adat, agama yang diyakini dan yang di tetapkan. Ingin merubaha menjadi yang lebih baik/ sempurna berdasarkan norma yang berlaku, sehingga adanya peningkatanpeningkatan perubahan yang bertahap. Dan adanya mengikuti perkembangan zaman sesuai kebutuhan masyarakat Aceh.

\section{KESIMPULAN}

Tari Seudati merupakan salah satu tarian tradisional berkembang dan hidup di kalangan masyarakat Aceh. Tari ini berfungsi sebagai 
sarana hiburan dan sebagai sarana media dakwah. Sekarang Tari Seudati terbagi atas dua jenis yaitu Tari Seudati agam (seudati laki-laki) ditetapkan sebagai tarian tradisional sedangkan Tari Seudati inong (seudati perempuan) ditetapkan sebagai tari kreasi di karnakan tari seudati inong adalah pengembangan dari seudati agam.

Perubahan yang terjadi di karnakan berkembangnya perkembangan zaman sesuai dengan kebutuhan masyarakat dimana ada penambahan norma-norma, nilai-nilai, adat dan agam yang harus disesuaikan dengan keperluan pada masa itu. Perubahan yang dilakukan dengan jangka waktu yang lama di karenkan harus bertahap dan beransur-ansur di mana masyarakat harus tetap menjaga warisan budaya dari nenek moyang, dan tidak mudah bagi masyarakat Aceh untuk meneri perubahan-perubahan baru yang ditetapkan pada masyarakat Aceh.

Perubahan-perubahan ini bertujuan untuk meningkatkan hasil kebudayaan yang terus menerus berkembang menurut zamannya. Di setiap perubahan maka beda pula tujuannya, seperti pada Tari Seudati pertama kali berubah tujuannya untuk meningkatkan dan menjaga ke kokohan masyarakat Aceh dalam menjalankan hidup sesuai ajaran agama Islam, sedangkan perubahan yang kedua pada Tari Seudati adalah untuk meningkatkan kualitas budaya yang berkembang di masa modern sesuai kebutuhan masyarat, tanpa mengurangi norma-norma, nilai-nilai, adat dan agama yang telah lama di tanamkan pada masyarakat Aceh.

\section{DAFTAR PUSTAKA}

Isjkarim, dkk. 1981. Kesenian Tradisional Aceh. Banda Aceh: Departemen Pendidikan dan Kebudayaan.

Martono, N. 2013. "Sosiologi Perubahan Sosial" PersepektifKlasik, Midern, Posmodern dan Poskolinial. Jakarta: PT Raja Grafindo Persada

Ranjabar, J. 2014. "Perubahan Sosial" Teoriteori dan Proses Perubahan Sosial serta Teori Pembangunan. Bandung: Alfabeta, $\mathrm{cv}$.

Wirahandoyo, S. 2002. "Perubahan Sosial" Sketsa Teori Dan Refleksi Metodologi Kasus Indonesia. Yogyakarta: Tiara Wacana Yogya. 